\title{
Primary Small Cell Carcinoma of the Tonsil: A Case Report and Review of the Literature
}

\author{
Amikar Sehdev $^{\mathrm{a}}$ Yujie Zhao $^{\mathrm{b}}$ Anurag K. Singh ${ }^{\mathrm{c}}$ \\ Neelesh Sharmad \\ ${ }^{a}$ Hematology and Medical Oncology, University of Chicago, Chicago, III., \\ Departments of ${ }^{b}$ Medical Oncology and ${ }^{\mathrm{c}}$ Radiation Medicine, Roswell Park \\ Cancer Institute, Buffalo, N.Y., and ${ }^{\mathrm{d} D e p a r t m e n t}$ of Medical Oncology, \\ University Hospital/CWRU, Cleveland, Ohio, USA
}

\section{Key Words}

Tonsillar cancer · Neuroendocrine tumor - Small cell cancer · Carboplatin · Etoposide

\begin{abstract}
Small cell cancer (SCC) of the tonsil is a rare and aggressive cancer. There are only 10 cases of tonsillar SCC reported in the English literature. We present a case of tonsillar SCC successfully treated with induction chemotherapy using carboplatin and etoposide followed by concurrent chemoradiation therapy with cisplatin as radiosensitizer. The patient remained free of recurrence after 3 years of follow-up. We also provide a succinct review of all tonsillar SCC cases reported in the English literature and their outcomes.
\end{abstract}

\section{Introduction}

Small cell cancer (SCC) displays aggressive biologic behavior and is associated with relatively poor prognosis. Although bronchogenic SCC is most common, origin from gastrointestinal, genitourinary, breast, head and neck and unknown primary have been reported. Multiple primaries as part of nonfamilial multiple endocrine tumors have also been reported [1]. The first case of SCC in the head and neck localized to the larynx was reported in 1972 [2]. According to a recent review by Renner [3], extrapulmonary SCC constitutes about $2.5-5 \%$ of all SCCs [4]. SCC in the head and neck mainly arise from larynx, salivary glands, nose and paranasal sinuses. The cell origin of the head and neck SCC was initially thought to be from amine-precursor uptake and decarboxylase (APUD or Kulchitsky) cells; however, the current opinion favors their origin from multipotential stem cells [3-5]. 


\section{Case Presentation}

A 53-year-old Caucasian female noted a lump in the right side of her neck, which was initially treated by her primary care physician with antibiotics without any effect. The mass continued to enlarge. Fine-needle aspiration of the right neck mass performed at an outside hospital was positive for poorly differentiated carcinoma. She was referred to our institution for further management. Her past medical history was notable for hypertension, 10 pack-year history of smoking, and occasional alcohol intake. Physical examination was significant for a solitary, right level II neck mass, $3.5 \times 2.5 \mathrm{~cm}$ in size with intact overlying skin. The remainder of the head and neck examination and laboratory tests were normal.

A computed tomography (CT) scan of the neck showed a $3.5 \times 2.8 \mathrm{~cm}$ well-circumscribed, enhancing, necrotic appearing mass posterior to the right submandibular gland and increased

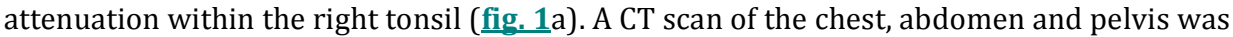
unremarkable. Whole body positron emission tomography - computed tomography (PET-CT) showed a prominent collection of fluorodeoxyglucose within an enlarged necrotic appearing level II lymph node, oropharynx and right tonsillar fossa without any evidence of distant metastatic disease (fig. 1a). Panendoscopy under anesthesia showed a very small exophytic tumor involving the right palatine tonsil. Several biopsies were taken and sent for histology.

Histopathologic review of the tonsillar lesion demonstrated poorly differentiated neoplasm with fine nuclear chromatin, small or inconspicuous nucleoli, scant cytoplasm, nuclear molding, numerous mitotic figures and apoptotic bodies, features consistent with small cell carcinoma (SCC) (shown by the arrow in fig. 2a). Immunophenotypically the tumor showed weak reactivity to cytokeratin AE1/3, cytokeratin 5/6, and synaptophysin (shown by the arrow in fig. 2b). Markers for chromogranin A, S-100, HMB-45, and CD56 were negative. The cytology of fine-needle aspiration of the right neck mass was also consistent with SCC. The patient was diagnosed with poorly differentiated neuroendocrine carcinoma (SCC) of the right tonsil with metastatic disease to neck, stage III, T1N2a.

The patient received a total of 3 cycles of induction chemotherapy with carboplatin AUC 6 and etoposide $100 \mathrm{mg} / \mathrm{m}^{2}$ on days $1-3$, every 4 weeks. Following induction treatment, a CT scan of the neck showed partial response in the predominantly necrotic right level II cervical lymph node. After the induction chemotherapy, the patient was started on concurrent chemoradiation with cisplatin at $30 \mathrm{mg} / \mathrm{m}^{2}$ every week with daily radiation therapy. She received a total dose of $70 \mathrm{~Gy}$ of intensitymodulated radiation therapy in 35 daily fractions of 2 Gy with 6 MV photons to the pretreatment gross tumor volume with a margin and 56 Gy to the at-risk lymph nodes. A follow-up CT of the neck after completion of chemoradiation therapy showed a significant reduction in the size of the right level II lymph node to $9 \mathrm{~mm}$ (fig. 1b). The right tonsil mass had completely resolved. A follow-up whole body PET-CT performed 12 weeks after the treatment demonstrated a complete metabolic response to therapy (fig. 1b). The patient has been followed for more than 3 years without any evidence of recurrence.

\section{Discussion}

Tonsillar SCC occurs most often in the 5 th to 7 th decades, and is more common in males than females (2:1 ratio). The tumor commonly presents clinically as a painless neck mass. Although paraneoplastic syndromes including SIADH, Cushing's syndrome and Eaton-Lambert myasthenic syndrome have been associated with head and neck SCC, there are no reports of these syndromes being associated with tonsillar SCC [3]. Besides the locoregional spread to cervical lymph nodes, the tumor metastasizes most commonly to liver, lungs, bones, brain and skin [6].

We conducted a thorough English literature search on PubMed using the search terms 'neuroendocrine tumors', 'small cell cancer', 'oat cell cancer' or 'apudoma', and 'head and neck' or 'tonsil'. All case reports or case series that included a case of tonsillar SCC were included. We found a total of only 10 cases of tonsillar neuroendocrine 
tumor; table 1 summarizes the clinical characteristics and treatment outcome of these case reports.

In the available case reports, treatment modalities included chemotherapy, radiotherapy, surgical resection or combinations of these modalities. In the absence of prospective controlled studies, treatment recommendations are based on retrospective analysis, and treatment guidelines for small cell lung cancer (SCLC). Overall survival of extrapulmonary SCC is longer than SCLC $[1,7,8]$. In our review, the median survival for SCC of the tonsil was 18 months. Our patient has achieved a disease-free survival of more than 3 years after completion of therapy.

SCC tends to be very aggressive with a propensity for developing early regional lymphatic and systemic metastases. Many investigators propose to consider SCC as a 'systemic' disease from the onset as distant metastasis is common [3]. In contrast, primary squamous cell cancer of the head and neck has a low tendency for distant metastatic disease, and local recurrence is the main concern. Treatment modalities targeting local disease such as surgery or radiation may be appropriate for squamous cell cancer of the head and neck, but may not be optimal for SCC in this region. Systemic chemotherapy should be part of the treatment in all stages of SCC. Our choice of chemotherapy regimen for induction was extrapolated from the data for SCLC, which in general is very sensitive to systemic chemotherapy doublet of platinum and etoposide, achieving a response rate of $60 \%$ to $70 \%$ with chemotherapy alone. Our patient achieved near complete response with induction chemotherapy which was followed by definitive chemoradiation.

\section{Conclusion}

SCC of the tonsil is an extremely rare entity with an aggressive disease course and poor prognosis. Therefore, it is important for the clinicians to be aware of the uncommon occurrence of this disease and its management. Finally, based on our report, the tonsil should be considered as possible primary site in patients presenting with metastatic SCC to the neck in which the primary tumor is not readily identifiable during the initial clinical examination. 
Table 1. Description of the cases of tonsillar SCC reported in the literature

\begin{tabular}{|c|c|c|c|c|c|}
\hline $\begin{array}{l}\text { Patient } \\
\text { No. }\end{array}$ & Authors & Age/sex & Presentation & Treatment modality & Status \\
\hline 1 & \multirow[t]{3}{*}{$\begin{array}{l}\text { Koss et al. [9] } \\
1972\end{array}$} & 70/female & $\begin{array}{l}\text { Tonsil mass } 5 \mathrm{~cm} \text {, with neck } \\
\text { nodes and disseminated } \\
\text { metastasis }\end{array}$ & Radiation only & Died after 8 months \\
\hline 2 & & $60 /$ male & $\begin{array}{l}\text { Occult tonsil mass with neck } \\
\text { nodes }\end{array}$ & $\begin{array}{l}\text { Radical neck dissection } \\
\text { and radiation }\end{array}$ & Died after 18 months \\
\hline 3 & & $54 /$ male & $\begin{array}{l}\text { Tonsil mass } 3.5 \mathrm{~cm} \text {, with neck } \\
\text { nodes }\end{array}$ & $\begin{array}{l}\text { Local excision and } \\
\text { radical neck dissection }\end{array}$ & Died after 5 years \\
\hline 4 & $\begin{array}{l}\text { Abedi and } \\
\text { Sismanis [6] } 1987\end{array}$ & $67 /$ female & $\begin{array}{l}\text { Left tonsil lesion and left neck } \\
\text { mass } 2 \times 3 \mathrm{~cm}\end{array}$ & $\begin{array}{l}\text { Radiation and } \\
\text { chemotherapy }\end{array}$ & Died after 6 months \\
\hline 5 & \multirow[t]{2}{*}{$\begin{array}{l}\text { Heimann et al. [1] } \\
1989\end{array}$} & $\begin{array}{l}78 / \text { not } \\
\text { reported }\end{array}$ & Left neck mass $5 \times 3 \times 3 \mathrm{~cm}$ & $\begin{array}{l}\text { Left radical neck } \\
\text { dissection }\end{array}$ & $\begin{array}{l}\text { Died after } 2 \text { years from cardiac } \\
\text { arrest during surgery for removal of } \\
\text { left tonsillar fossa recurrent tumor }\end{array}$ \\
\hline 6 & & 74/male & $\begin{array}{l}\text { Enlarged left tonsil with cervical } \\
\text { and axillary lymphadenopathy }\end{array}$ & Chemotherapy & Died after 1 month from heart failure \\
\hline 7 & $\begin{array}{l}\text { Bawa and Wax } \\
\text { [10] } 1995\end{array}$ & $53 /$ male & $\begin{array}{l}\text { Left tonsil enlargement and left } \\
\text { neck mass }\end{array}$ & $\begin{array}{l}\text { Radiation and } \\
\text { chemotherapy }\end{array}$ & Died after 15 months \\
\hline 8 & \multirow{3}{*}{$\begin{array}{l}\text { Hatoum et al. [8] } \\
-2008\end{array}$} & $49 /$ male & Reported as T1N3 tonsillar cancer & \multirow{3}{*}{$\begin{array}{l}\text { Chemotherapy and } \\
\text { radiation }\end{array}$} & Died after 30 months \\
\hline 9 & & $50 /$ male & Reported as T3N1 tonsillar cancer & & $\begin{array}{l}\text { Alive at } 9 \text { years of reported } \\
\text { follow-up without recurrence }\end{array}$ \\
\hline 10 & & $50 /$ female & $\begin{array}{l}\text { Reported as T4N2b tonsillar } \\
\text { cancer }\end{array}$ & & $\begin{array}{l}\text { Alive at } 18.4 \text { months of reported } \\
\text { follow-up without recurrence }\end{array}$ \\
\hline
\end{tabular}
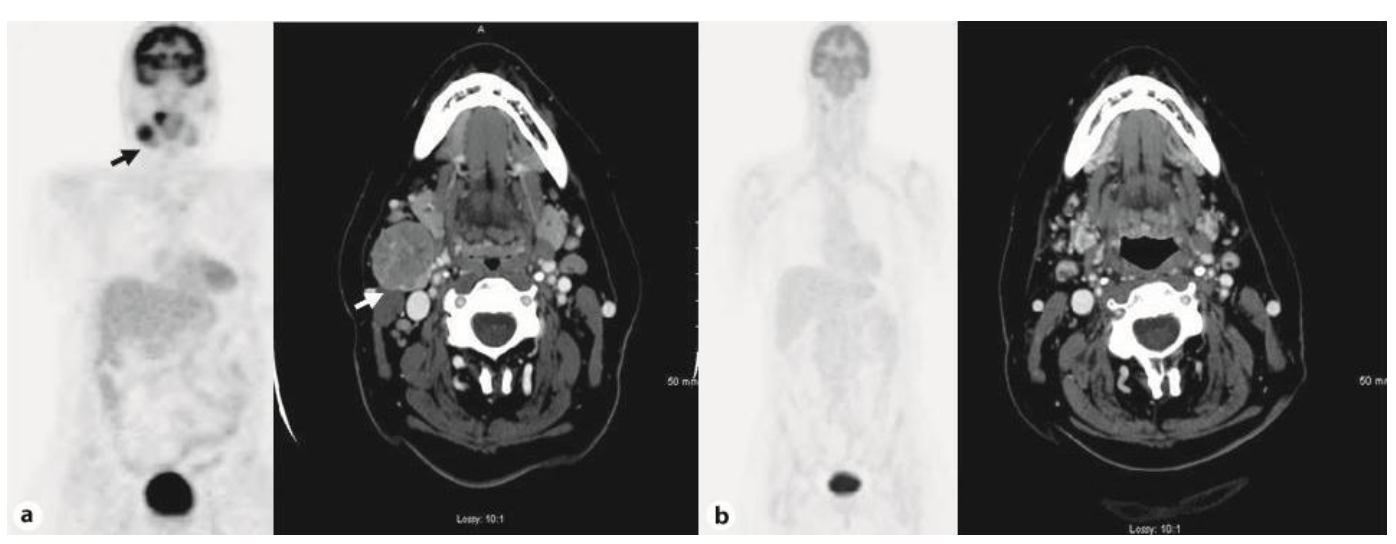

Fig. 1. a, b A CT scan of the neck and PET scan showing a hypermetabolic, $3.5 \times 2.8 \mathrm{~cm}$, wellcircumscribed mass posterior to the right submandibular gland and increased attenuation within the right tonsil (a). A repeat CT and PET scan showing complete resolution of this mass 12 weeks after the treatment (b). 

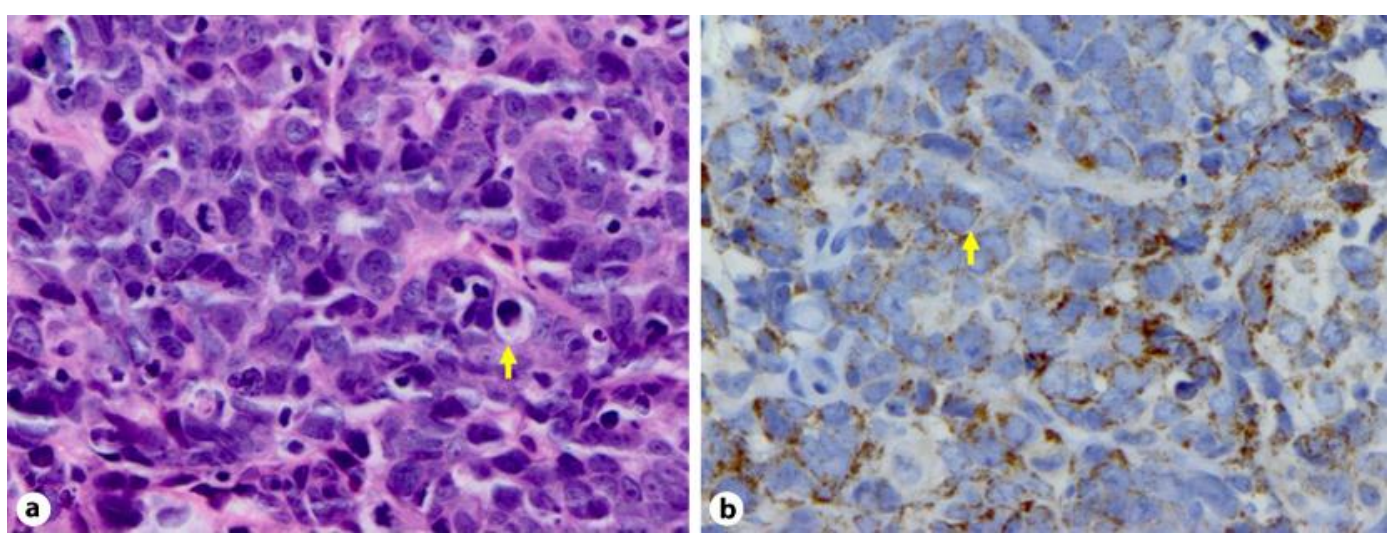

Fig. 2. a, b Histological appearance of the tumor. HE-stained tumor showing poorly differentiated neoplasm with fine nuclear chromatin, small nucleoli, scant cytoplasm and numerous mitotic figures (a). Cytoplasmic synaptophysin staining of the tumor cells (b).

\section{References}

1 Heimann R, Dehou MF, Lentrebecq B, et al: Anaplastic small cell (oat cell) carcinoma of the tonsils: report of two cases. Histopathology 1989;14:67-74.

-2 Olofsson J, Van Nostrand AW: Anaplastic small cell carcinoma of larynx. Case report. Ann Otol Rhinol Laryngol 1972;81:284-287.

3 Renner G: Small cell carcinoma of the head and neck: a review. Semin Oncol 2007;34:3-14.

4 van der Heijden HF, Heijdra YF: Extrapulmonary small cell carcinoma. South Med J 2005;98:345-349.

5 Bensch KG, Corrin B, Pariente R, et al: Oat-cell carcinoma of the lung. Its origin and relationship to bronchial carcinoid. Cancer 1968;22:1163-1172.

-6 Abedi E, Sismanis A: Extrapulmonary oat-cell carcinoma of the tonsil. Ear Nose Throat J 1987;66:112115.

7 Remick SC, Hafez GR, Carbone PP: Extrapulmonary small-cell carcinoma. A review of the literature with emphasis on therapy and outcome. Medicine (Baltimore) 1987;66:457-471.

8 Hatoum GF, Patton B, Takita C, et al: Small cell carcinoma of the head and neck: the university of Miami experience. Int J Radiat Oncol Biol Phys 2009;74:477-481.

9 Koss LG, Spiro RH, Hajdu S: Small cell (oat cell) carcinoma of minor salivary gland origin. Cancer 1972;30:737-741.

10 Bawa R, Wax MK: Small cell carcinoma of the tonsil. Otolaryngol Head Neck Surg 1995;113:328-333. 